College of William \& Mary Law School William \& Mary Law School Scholarship Repository

2008

\title{
The Domestic Incorporation of Human Rights Law and the United Nations Convention on the Rights of Persons with Disabilities
}

Janet E. Lord

Michael Ashley Stein

\section{Repository Citation}

Lord, Janet E. and Stein, Michael Ashley, "The Domestic Incorporation of Human Rights Law and the United Nations Convention on the Rights of Persons with Disabilities" (2008). Faculty Publications. 665.

https://scholarship.law.wm.edu/facpubs/665 


\title{
THE DOMESTIC INCORPORATION OF HUMAN RIGHTS LAW AND THE UNITED NATIONS CONVENTION ON THE RIGHTS OF PERSONS WITH DISABILITIES
}

\author{
Janet E. Lord" \& Michael Ashley Stein ${ }^{* *}$ \\ Abstract: This Article reviews the processes by which domestic-level transposition of \\ international human rights norms may occur as a consequence of human rights treaty \\ ratification, or other means of incorporation. Specifically, we consider the transformative \\ vision of the Convention on the Rights of Persons with Disabilities (CRPD or Convention) as \\ a vehicle for fostering national-level disability law and policy changes. In doing so, we \\ outline the challenges and opportunities presented by this new phase in disability rights \\ advocacy, and we draw conclusions that bear generally upon human rights practice and \\ scholarship. We contend that the role of human rights in domestic law and process reflect \\ important dimensions of international law and practice. At the same time, human rights \\ advocates and scholars often fail to account for the potentially mutually constitutive nature of \\ domestication processes and the transformative role that human rights treaties perform within \\ societies. Accordingly, we argue that effective Convention implementation must result in a \\ human rights practice that includes law reform or court-based advocacy, but also moves \\ beyond it to include strategies that support deeper domestic internalization of human rights \\ norms.
}

INTRODUCTION 450

I. PROCESSES OF DOMESTIC INCORPORATION.... 452

II. THE TRANSFORMATIVE VISION OF THE CRPD IN FOSTERING NATIONAL-LEVEL CHANGE

A. General Obligations ...........................................457

B. General Principles and the Framing of Disability ............460

C. Other Cross-Cutting Articles .................................461

D. Substantive Provisions...........................................461

E. Monitoring at the National Level...................................462

F. Facilitating National-Level Change..............................465

\footnotetext{
* Partner, BlueLaw International, LLP; Research Associate, Harvard Project on Disability.

** Executive Director, Harvard Project on Disability; Visiting Professor, Harvard Law School; Cabell Research Professor, William \& Mary School of Law.

We are grateful to the participants in this symposium for their thoughtful comments; to Lauren Hughes and Genevieve Jenkins for their research assistance; and to Paul Miller for inviting our participation in a rich and productive forum. Our research was funded in part by a grant from Foundation Open Society ( $\mathrm{Zug}$ ). For further information on the domestic disability law and policy reform work referenced in this Article by the Harvard Project on Disability, see http:/www.hpod.org, permanent copy available at http://www.law.washington.edu/wlr/notes/83washlrev449n0.pdf.
} 


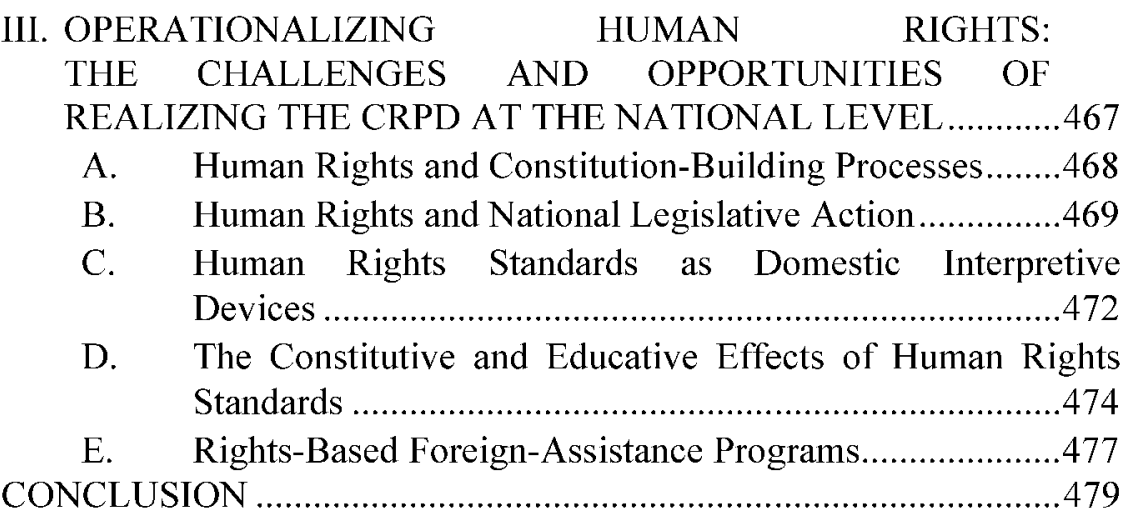

\section{INTRODUCTION}

The United Nations adopted the Convention on the Rights of Persons with Disabilities (CRPD or Convention) ${ }^{1}$ along with its Optional Protocol ${ }^{2}$ by general consensus on December 13, 2006. ${ }^{3}$ The CRPD opened for signature by States Parties on March 30, 2007, and a vast majority of States signed it soon thereafter. It attained the requisite twenty ratifications to trigger entry into force on May 3,2008. ${ }^{4}$

As the first human rights treaty of the twenty-first century, as well as the first legally enforceable United Nations instrument specifically directed at the rights of persons with disabilities, the Convention ushers in a new era of international human rights law and practice. ${ }^{5}$ Fewer than

1. Convention on the Rights of Persons with Disabilities, G.A. Res. 61/106, U.N. Doc. A/RES/61/106 (Jan. 24, 2007) [hereinafter CRPD], available at http:/www.un.org/esa/socdev/enable/rights/convtexte.htm, permanent copy available at http://www.law.washington.edu/wlr/notes/83washlrev449nl.pdf.

2. Optional Protocol to the Convention on the Rights of Persons with Disabilities, G.A. Res. 61/106, U.N. Doc. A/RES/61/106 (Jan. 24, 2007) [hereinafter Optional Protocol].

3. Press Release, General Assembly, General Assembly Adopts Groundbreaking Convention, Optional Protocol on Rights of Persons with Disabilities: Delegations, Civil Society Hail First Human Rights Treaty of Twenty-First Century, U.N. Doc. GA/10554 (Dec. 13, 2006), available at http:/www.un.org/News/Press/docs/2006/ga10554.doc.htm, permanent copy available at http://www.law.washington.edu/wlr/notes/83washlrev449n3.pdf.

4. The CRPD text, along with its drafting history, resolutions, and updated list of States Parties is posted on the United Nations Enable website. See U.N. Enable, Promoting the Rights of Persons with Disabilities: Full Participation and Equality in Social Life and Development (2006), http:/www.un.org/esa/socdev/enable/rights/, permanent copy available at http://www.law.washington.edu/wlr/notes/83washlrev449n4.pdf.

5. See generally Michael Ashley Stein, Disability Human Rights, 95 CAL. L. REV. 75 (2007). 
fifty States Parties have any sort of systemic disability legislation, ${ }^{6}$ and many of those are in need of drastic revision? In addition, the Convention mandates that its monitoring Committee review measures taken by States Parties to incorporate the treaty's obligations into domestic legal frameworks. ${ }^{8}$ States Parties are obligated to undertake a wide range of national-level implementation measures (some familiar to human rights treaties, and others reflecting obligations more frequently found in other international law contexts), in order to give full effect to the CRPD provisions. ${ }^{9}$ Consequently, the CRPD initiates an unprecedented opportunity for domestic law, policy reform, and genesis on behalf of the globe's "largest minority."

This Article reviews the processes by which domestic-level transposition of international human rights norms may occur as a consequence of human rights treaty ratification or incorporation. ${ }^{11}$

6. For a catalogue circa 2002, see Theresia Degener \& Gerard Quinn, A Survey of International, Comparative and Regional Disability Law Reform, in DiSABILITY RIGHTS LAW AND POLICY: International and National PERSPECtives 3, 25-45 (Mary Lou Breslin \& Sylvia Yee eds., 2002). Over the last two years, the authors have been involved in disability-related law reform in roughly a dozen countries. For our perspective, see Michael Ashley Stein \& Janet E. Lord, The United Nations Convention on the Rights of Persons with Disabilities as a Vehicle for Social Transformation, in NATIONAL MONITORING MECHANISMS OF THE CONVENTION ON THE RIGHTS OF PERSONS WITH DISABILITIEs (Comisión Nacional de los Derechos Humanos ed., forthcoming 2008) available at http://www.law.washington .edu/wlr/notes/83washlrev449n6.pdf.

7. See Michael Ashley Stein \& Penelope J.S. Stein, Beyond Disability Civil Rights, 58 HaSTTNGS L.J. 1203, 1203 (2007) ("[A] growing number of countries ... have enacted disability-related legislation. Unfortunately, the continuing economic inequities and social exclusion of disabled persons worldwide severely calls into doubt the efficacy of these efforts. It also begs the question of whether any country adequately protects their disabled citizens.").

8. See CRPD, supra note 1 , art. 35-36; Optional Protocol, supra note 2, art.13 (1).

9. See CRPD, supra note 1 , art. 30 .

10. International Convention on the Rights of Persons with Disabilities, Some Facts ABOUT PERSONS WITH DISABILITIES 1 (2006), available at http://www.un.org/disabilities/convention/pdfs/factsheet.pdf, permanent copy available at http://www.law.washington.edu/wlr/notes/83washlrev449n10.pdf.

11. In order for a treaty to have domestic legal effect, an act of government is frequently required to incorporate the treaty into domestic law. Such legal systems are considered "dualist" in nature, in contrast with "monist" systems where the State's legal system is considered to include international treaties without the need for separate, domestic-level action. See generally J.G. Starke, Monism and Dualism in the Theory of International Law, 17 BRIT. Y.B. INT'L L. 66 (1936). While this traditional distinction between dualist and monist States has been criticized, it does help to underscore a fundamental difference among legal systems that impacts the reception of international-treaty obligations. Human rights scholars and practitioners must take heed of this distinction. For clear treatments of the domestic legal effects of treaties, and international law more generally, see Rosalyn Higgins, Problems and Process: International LaW and How We USE It 205-18 (1994); Malcolm N. Shaw, Internattonal Law 99-136 (4th ed. 1997); John H. Jackson, Status 
Specifically, we consider the transformative vision of the CRPD as a vehicle for fostering national-level disability law and policy changes. In doing so, we outline the challenges and opportunities presented by this new phase in disability rights advocacy and draw conclusions that bear more generally upon human rights practice and scholarship. ${ }^{12}$

Part I of this Article explains the processes influencing domestic incorporation of the CRPD. Next, Part II examines ways the Convention seeks to transform the respective domestic laws-and social processesof States Parties. Finally, Part III explores some of the challenges faced by States Parties in adopting the CRPD into domestic legal regimes and in achieving the transformative social change envisioned by the Convention drafters.

\section{PROCESSES OF DOMESTIC INCORPORATION}

It is axiomatic that international human rights standards are implemented domestically, ${ }^{13}$ and are intended to take root through processes of domestic incorporation. ${ }^{14}$ Human rights treaties reflect this most basic idea in provisions that create obligations at the international level to be given effect at the domestic level, thereby ensuring

of Treaties in Domestic Legal Systems: A Policy Analysis, 86 AM. J. INT'L L. 310, 314-15 (1992).

12. For earlier accounts that were drawn upon for this chapter, see Janet E. Lord \& Michael Ashley Stein, The Committee on the Rights of Persons with Disabilities, in THE UNITED NATIONS AND Human Rights: A CRITTCAL APPRAISAL (Philip Alston \& Frédéric Mégret eds,, forthcoming 2008), available at http:/www.law.washington.edu/wlr/notes/83washlrev449n12a.pdf; Michael Ashley Stein \& Janet E. Lord, Future Prospects for the United Nations Convention on the Rights of Persons with Disabilities, in THE UN CONVENTION ON THE RIGHTS OF PERSON WTTH DISABILITIES: EuROPEAN AND SCANDINAVIAN PERSPECTIVES (Oddný Mjöll Arnardóttir \& Gerard Quinn eds., forthcoming 2008), available at http://www.law.washington.edu/wlr/notes/83washlrev449n 12b.pdf; Michael Ashley Stein \& Janet E. Lord, The Normative Value of a Treaty as Opposed to a Declaration: Reflections from the Convention on the Rights of Persons with Disabilities, in Implementing the Right to Development 27-32 (Stephen P. Marks ed., 2008); Stein, supra note 5 .

13. Thomas Buergenthal, Dinah Shelton \& David Stewart, international human RIGHTS IN A NUTSHELL 347 ( 2 d ed. 2002).

14. There is an extensive literature on the domestic incorporation of human rights standards and the processes by which this occurs. See, e.g., THE EFFECTS OF TREATIES IN DOMESTIC LAW (Francis G. Jacobs and Shelley Roberts eds., 1987); Antonio Cassesse, Modern Constitutions and International Law, 192 RECuEIL Des CouRs 331 (1985); Felice Morgenstern, Judicial Practice and the Supremacy of International Law, 27 BRIT. Y.B. INT'L L. 42 (1950); Ignaz Seidl-Hohenveldern, Transformation or Adoption of International Law into Municipal Law, 12 INT'L \& COMP. L.Q. 88 (1963); Luzius Wildhaber \& Stephan Breitenmoser, The Relationship between Customary International Law and Municipal Law in Western European Countries, 48 HEIDELBERG J. INT'L. L. 163 (1988) 
meaningful translation of international norms into national-level action. $^{15}$

Notwithstanding the practical transposition of human rights treaties occurring domestically, these instruments do, of course, have significant currency at the international level where they may receive high-profile monitoring or trigger judicial application through communication procedures. Much of the literature focusing on domestic incorporation privileges the more prominent features of law reform and treaty ratification, and court-driven applications of international rules. ${ }^{16}$ Such work is perhaps inspired by the international lawyer's project to prove the relevance and content of international law to an often skeptical audience of positivists. ${ }^{17}$ Yet, human rights practice, whether at the national or international level, tends to pay particular heed to legal interventions of one sort or another, while disregarding that broader spectrum of rights-oriented work that is vital to social transformation, such as human rights education, media engagement, budgetary analysis and advocacy, grassroots empowerment, and mobilization.

More specifically, there is a pattern among human rights advocates and scholars to focus narrowly on law reform and to invoke human rights norms before judicial or quasi-judicial bodies. This pattern reflects, perhaps, a common desire to assert legal relevance in the face of

15. See, e.g., Convention against Torture and Other Cruel, Inhuman or Degrading Treatment or Punishment arts. 2-16, G.A. Res. 39/46, U.N. Doc. A/39/51 (Dec. 10, 1984) (entered into force June 26, 1987) [hereinafter CAT]; Convention on the Elimination of All Forms of Discrimination Against Women arts. 2-6, G.A. Res. 34/180, U.N. Doc. A/34/46 (Dec. 18, 1979) (entered into force Sept. 3, 1981) [hereinafter CEDAW]; International Covenant on Civil and Political Rights arts $1-5$, G.A. Res. 2200A (XXI), U.N. Doc. A/6316, 999 U.N.T.S. 171 (Dec. 16, 1966) (entered into force Mar. 23, 1976) [hereinafter ICCPR]; International Convention on the Elimination of All Forms of Racial Discrimination arts. 2-7, G.A. Res. 2106 (XX), U.N. Doc. A/6014, 660 U.N.T.S. 195 (Dec. 21, 1965) (entered into force Jan. 4, 1969) [hereinafter CERD].

16. See, e.g., SHAw, supra note 11, at 99-136; BUERGENTHAL, SHELTON \& STEWART, supra note 13 , at 247.

17. See generally Michael Byers, Custom, POWER AND the POWER OF RUles: INTERNATIONAL RELATIONS AND CUSTOMARY INTERNATIONAL LAW (1999) (noting the preoccupation of international legal scholarship with proving the content and relevance of international law and applying an interdisciplinary perspective to the study of power and rules within the customary-international-law process). Positivist approaches, as applied to the problem of translating international legal obligations into domestic law frameworks, understand municipal and international law as occupying separate and distinct realms, with international law made real only through the express legislative incorporation into domestic law. See generally SHAW, supra note 11, at 100-02; Harold Hongju Koh, Why Do Nations Obey International Law?, 106 YALE L.J. 2599, 2608-11 (1997). 
persistent violations and governmental apathy. ${ }^{18}$ Similarly, in international development, domestic incorporation of human rights law is often characterized exclusively within the parameters of top-down, rule of law programming. ${ }^{19}$ As a result, national-level action becomes primarily a project to reform constitutions, organizational, procedural and substantive laws, and the justice sector. ${ }^{20}$

Although these perspectives on the role of human rights in domestic law and process reflect important dimensions of international law and practice, they are not the sum total of human rights work. Indeed, they overlook the potentially mutually constitutive nature of domestication processes and the transformative role that human rights treaties play within societies. ${ }^{21}$ Human rights practice increasingly is understood to

18. This may have as much to do with the limits of the international legal scholar's engagement with the broad spectrum of human rights work as it does with the narrowness of traditional human rights practice. This constriction is best reflected in the traditional focus of human rights advocacy on civil and political rights, chiefly through the mechanism of monitoring and reporting on violations. See, e.g., Kenneth Roth, Defending Economic, Social and Cultural Rights: Practical Issues Faced by an International Human Rights Organization, 26 HUM. RTs. Q. 63 (2004) (explaining that nongovernmental organizations (NGOs) are most effective when they concentrate on using shaming methods against clear civil and political human rights violations). Such an approach pushes economic, social, and cultural rights along with other forms of human rights promotion to the margins, especially for socially vulnerable groups. See also Janet E. Lord \& Katherine N. Guernsey, It Takes a Treaty: Elbowing into the Human Rights Mainstream (March 2004) (paper submitted to the International Studies Association Annual Meeting, Montreal, Canada), available at http:/www.law.washington.edu/wlr/notes/83washlrev449n18.pdf.

19. See, e.g., Joshua G. Smith, Victoria K. Holt \& William J. Durch, Enhancing United Nations Capacity to Support Post-Conflict Policing and Rule of Law (2007), available at http://www.stimson.org/pub.cfm?ID=483, permanent copy available at http://www.law.washington.edu/wlr/notes/83washlrev449n19.pdf.

20. USAID rule of law programming typifies this approach and is heavily focused on both providing technical-assistance services privileging legal-framework reforms and training government officials and the judiciary. Sustained work to facilitate the effective engagement of civil-society actors in rule of law efforts, which could help to ensure that human rights ideas establish deep roots, is a lower programming priority. See, e.g., USAID, User's Guide to $D G$ Programming 25-35, 41-15 (June 2006), available at http://www.usaid.gov/our_work/democracy_and_governance/publications/pdfs/ug.pdf, permanent copy available at $\mathrm{http} / /$ www.law.washington.edu/wlr/notes/83washlrev449n20.pdf (cataloguing technical-assistance services in the rule of law realm with primary emphasis on top-down interventions). For an excellent analysis of the limitations of transformative social change via legal interventions alone, see Smita Narula, Equal by Law, Unequal by Caste: The "Untouchable" Condition in Critical Race Perspective, 26 WIS. INT'L L.J. 255 (2008) (arguing that constitutional and legislative approaches to addressing caste-based discrimination have not led to transformative social change).

21. Of particular interest in this context is international relations scholarship that looks to the role played by normative structures - rules, principles, and processes of international law - and claims that participation in human rights process is mutually constitutive, transforming actor identities and 
occupy a much larger realm; domestic internalization of human rights norms cause micro-processes of acculturation that form the backbone of lasting social change. ${ }^{22}$

These developments formed part of the basis for negotiating the CRPD, together with the long-held view of disability rights advocates, which is that the mainstream human rights movement had failed disabled persons. ${ }^{23}$ As a consequence, those involved in the drafting of the CRPD attempted to build a framework within which the Convention's eventual domestic incorporation would evolve beyond current human rights practice toward a broader transformative vision. ${ }^{24}$

interests. See generally MARGARET KeCK \& KATHRYN SIKKINK, ACTIVISTS BEYOND BORdERs:

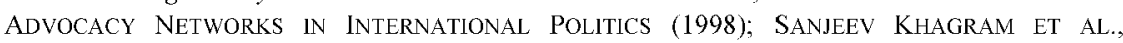

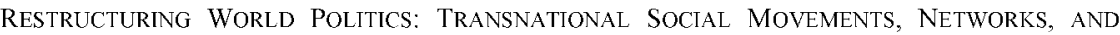
NORMS (2002); THE THIRD FORCE: THE RISE OF TRANSNATIONAL CIVIL SOCIETY (Ann Florini ed., 2000). More broadly, such work shows promise for explaining how systems of shared ideas, beliefs, and values work to influence social and political action. See, e.g., Christian Reus-Smit, Constructivism, in THEORIES OF INTERNATIONAL RELATIONS 209, 216-18 (Scott Burchill et al. eds., 2001).

22. The work of Ryan Goodman and Derek Jinks captures well how this important work could nonetheless be vitally enriched by interrogating an additional mechanism of social influence in human rights process. They point to shortcomings in the predominant mechanisms used to explain the power of human rights law-coercion and persuasion-and assert that coercion "fails to grasp the complexity of the social environment within which states act" and that persuasion "fails to account for many ways in which the diffusion of social and legal norms occurs." Ryan Goodman \& Derek Jinks, How to Influence States: Socialization and International Human Rights Law, 54 DuKE L.J. 621, 625 (2004); see also Ryan Goodman \& Derek Jinks, Toward an Institutional Theory of Sovereignty, 55 STAN. L. REV. 1749 (2003). Their conceptual framework for another mechanism of social influence-acculturation-is compelling, particularly insofar as it can help to explain the relational dynamics occurring within a contested human rights treaty process and against a highly relevant existing normative framework. Thus, acculturation, defined as "the general process by which actors adopt the beliefs and behavioral patterns of the surrounding culture" helps analyze mechanisms of influence at work within human rights law-making processes. Goodman \& Jinks, How to Influence States, supra at 626

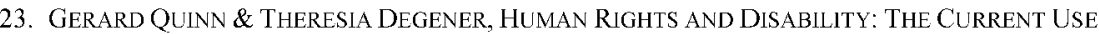
AND Future PotentIAL OF UNited NATIONS HuMAN RiGHTS INSTRUMENTS IN THE CONTEXT OF DISABILITY 1 (2002), available at http:/www.nhri.net/pdf/disability.pdf, permanent copy available at http://www.law.washington.edu/wlr/notes/83washlrev449n23.pdf.

24. Official Statement, U.N. Secretary-General, Secretary-General Hails Adoption of Landmark Convention on Rights of People with Disabilities, U.N. Doc. SG/SM/10797 (Dec. 13, 2006), available at http:/www.un.org/News/Press/docs/2006/sgsm10797.doc.htm, permanent copy available at http:/Www.law.washington.edu/wlr/notes/83washlrev449n24a.pdf (stating that, once adopted, signed, and ratified, the Convention "will have an impact on national laws that will transform how people with disabilities can live their lives"); see also UN News Centre, Lauding Disability Convention as 'Dawn of a New Era,' UN Urges Speedy Ratification (Dec. 13, 2006), available at http://www.un.org/apps/news/story.asp? NewsID $=20975 \& \mathrm{Cr}=\mathrm{disab}$, permanent copy available at $\mathrm{http}: / / \mathrm{www}$.law.washington.edu/wlr/notes/83washlrev449n24b.pdf. 
This explains, at least in part, some of the more innovative structural and substantive elements of the CRPD. Whether and how these elements will actually work to transform the reception of disability rights standards through domestic processes of incorporation remains to be seen. Likewise, the capacity of national disability movements to access the multitude of advocacy entry points suggested by a full reading of the CRPD is as yet untested.

\section{THE TRANSFORMATIVE VISION OF THE CRPD IN FOSTERING NATIONAL-LEVEL CHANGE}

The vision offered by the CRPD for national-level action is farreaching and potentially transformative if taken up by States Parties and supported by disabled peoples organizations (DPOs), international development actors, and national human rights institutions (NHRIs) and mechanisms. The Convention sets forth a host of general obligations familiar to human rights treaties-prompting national law reform and domestic incorporation of its provisions. It also provides a framework for a holistic approach to national-level disability rights advocacy and action. ${ }^{25}$

Moving beyond the traditional frameworks of human rights conventions, the CRPD lays out a template for comprehensive action, providing catalysts for socialization and outlining integrative mechanisms designed to address the cross-cutting nature of disability. Thus, the CRPD includes an express mandate for education and raising awareness of disability rights. ${ }^{26}$ It calls for the establishment of governmental coordination mechanisms and independent national-level monitoring schemes to facilitate implementation and ensure an integrated approach that cuts across government. ${ }^{27}$ The Convention

25. See Stein, supra note 5, at 111-13 ("[B]ecause attitudes fomenting disability-related exclusion manifest to a greater degree in critiquing an environment's social construction, the framework provides an exemplar for why and how first- and second-generation rights applicable to women should be viewed and implemented holistically ....").

26. CRPD, supra note 1, art. 8 (mandating that States Parties "raise awareness throughout society, including at the family level, regarding persons with disabilities" and that States Parties also "promote awareness of the capabilities and contributions of persons with disabilities")

27. Id. art. 33 ("States Parties shall, in accordance with their legal and administrative systems, maintain, strengthen, designate or establish within the State Party, a framework, including one or more independent mechanisms, as appropriate, to promote, protect and monitor implementation of the present Convention. When designating or establishing such a mechanism, States Parties shall take into account the principles relating to the status and functioning of national institutions for protection and promotion of human rights."). 
clearly envisages a broader human rights practice ${ }^{28}$ that extends beyond monitoring and reporting on violations or top-down law-reform efforts. However, monitoring and reporting mechanisms are still critical, and form a core part of the implementation measures of the CRPD. ${ }^{29}$

Beyond traditional enforcement tools, the CRPD establishes a framework for implementation to foster international cooperation and inclusive development programming. ${ }^{30}$ This provision may extend CRPD standards, via development programming, to work change in discrete contexts such as electoral-law reform and practice, communitybased rehabilitation, and capacity building for DPOs, among others. As set forth in this section, the CRPD offers a transformative vision for fostering change at the domestic level.

\section{A. General Obligations}

States Parties to human rights treaties are required to give effect to their obligations within their domestic legal order. The principal vehicle for articulating the framework for these national-level requirements is the general obligations provision found in all of the core human rights conventions. ${ }^{31}$ Article 4 of the CRPD, much like other treaties, requires States Parties to give effect to Convention obligations within their domestic legal orders. ${ }^{32}$

Article 4 requires States Parties to undertake measures that ensure the promotion and full realization of all human rights and fundamental freedoms for all persons with disabilities, while also prohibiting any

\footnotetext{
28. For discussion of the impact of mainstream legal-centric approaches to human rights practice to the disregard of other forms of human rights advocacy, see Lord \& Guernsey, supra note 18, and Narula, supra note 20 , at $327-40$.

29. CRPD, supra note 1 , arts. $32-40$.

30. Id. art. 32 ("States Parties recognize the importance of international cooperation and its promotion, in support of national efforts for the realization of the purpose and objectives of the present Convention, and will undertake appropriate and effective measures in this regard, between and among States and, as appropriate, in partnership with relevant international and regional organizations and civil society, in particular organizations of persons with disabilities.") Article 32 lists examples of measures to promote international cooperation and inclusive programming. $I d$. art. 32.

31. See, e.g., CAT, supra note 15 , art. 2; CEDAW, supra note 15 , art. 2; ICCPR, supra note 15 , art. 2; CERD, supra note 15 , art. 2.

32. CRPD, supra note 1, art. 4 ("States Parties undertake to ensure and promote the full realization of all human rights and fundamental freedoms for all persons with disabilities without discrimination of any kind on the basis of disability."). Following the general statement of obligation, Article 4 lists responsibilities which the States Parties assume through their support of the CRPD. Id. art. 4.
} 
form of discrimination in the attainment of these rights. ${ }^{33}$ Specifically, the provision enumerates the obligations of States Parties: first, to adopt legislative, administrative, and other measures to implement the Convention, and second, to abolish or amend existing laws, regulations, customs, and practices that discriminate against persons with disabilities. ${ }^{34}$ Article 4 further requires States Parties to adopt an inclusive approach to protect and promote the rights of persons with disabilities in all policies and programs. ${ }^{35}$ Consistent with other human rights conventions, the CRPD provides that States must refrain from conduct that violates the Convention, and it also ensures that the public sector respects the rights of persons with disabilities. ${ }^{36}$ The CRPD likewise requires States to take measures to abolish disability discrimination by persons, organizations, or private enterprises. ${ }^{37}$

The general-obligations provision of the Convention in Article 4 may be implemented through a variety of methods beyond the enactment of legislative measures. ${ }^{38}$ The Convention requires States Parties to engage in the research and development of accessible goods, services, and technology for persons with disabilities, and to enable others to undertake such research. ${ }^{39}$ States are obligated to provide accessible information about assistive technology to persons with disabilities, ${ }^{40}$ and to promote professional and staff training on the Convention rights for those working with persons with disabilities on the Convention. ${ }^{41}$ Crucially, Article 4 requires States Parties to consult with and involve persons with disabilities both in developing and implementing legislation and policies, as well as and in making decisions concerning CRPD rights. ${ }^{42}$

Insofar as the implementation of economic, social, and cultural rights

33. Id. art. 4

34. Id. art. $4(1)(\mathrm{a})$.

35. Id. art. $4(1)(\mathrm{c})$.

36. Id. art. $4(1)(\mathrm{d})$

37. Id. art. $4(1)(\mathrm{e})$.

38. The method of translating international legal obligations into national law depends upon the nature of the domestic legal system. For a straightforward account of this process, see UNITED NATIONS, REPORT OF THE United NATIONS CONSUltative EXPERT GRoup MeETING ON INTERNATIONAL NORMS AND STANDARDS RELATING TO DISABILITY 10-20 (Dec. 8-12, 1998).

39. See CRPD, supra note 1 , arts. $4(1)(\mathrm{f}) \&(\mathrm{~g})$.

40. Id. art. $4(1)(\mathrm{h})$.

41. Id. art. 4(1)(i).

42. Id art. 4(3). 
is concerned, the CRPD takes the approach of other human rights treaties, particularly the Convention on the Rights of the Child. ${ }^{43}$ States Parties must progressively take measures to realize economic, social, and cultural rights to the maximum extent of their available resources. ${ }^{44}$ In keeping with treaty-body jurisprudence, this will require States Parties to "move as expeditiously and effectively as possible" toward full realization of rights. ${ }^{45}$ Vigorous monitoring of progress in this context will be essential; such monitoring must be performed by both nationallevel actors, including DPOs and NHRIs, as well as the Committee on the Rights of Persons with Disabilities. This work must amount to more than summary analysis of legislation and policy to encompass detailed analytical work. For example, budget analysis - a form of human rights advocacy pursued with increased vigor by the women's rights community-will be an essential component of any effective disability rights advocacy campaign at the national (and indeed local) level. ${ }^{46}$

43. Convention on the Rights of the Child, G.A. Res. 44/25, U.N. Doc. A/44/49 (Nov. 20, 1989) (entered into force Sept. 2, 1990) [hereinafter CRC]. Notably, however, the structure of the CRPD clarifies the relationship between non-discrimination and equality and economic, social, and cultural rights insofar as Article 5 (Non-Discrimination and Equality) and Article 3 (General Principles) are not stand-alone articles. Rather, they are articles of general application to be applied horizontally across the CRPD rights spectrum.

44. See CRPD, supra note 1 , art. 4(2).

45. U.N. Comm. on Econ., Soc. \& Cultural Rights, Compilation of General Comments and General Recommendations Adopted by Human Rights Treaty Bodies, General Comment 3, 20 , HRI/GEN/1/Rev.5 (Apr. 26, 2001).

46. Budget analysis refers to a process by which state allocation of resources are scrutinized and assessed, for example, to identify sufficiency of resource allocation in the attempt to secure the rights of a particularly disadvantaged group. See MARIA DIOKNO, A RIGHTS-BASED APPROACH TO BUDGET ANALYSIS 8 (1999), available at http:/www.iie.org/Website/CustomPages/ACFE8.pdf, permanent copy available at http://www.law.washington.edu/wlr/notes/83washlrev449n46a.pdf; FUNDAR, INTERNATIONAL HUMAN RIGHTS INTERNSHIP PROGRAM, INTERNATIONAL BUDGET ProjeCt, Dignity COUNTS: A GuIDE TO USING BUDGET ANALYSIS TO ADVANCE HUMAN RightS 1 (2004), available at $\mathrm{http}: / / \mathrm{www}$.iie.org/IHRIP/Dignity_Counts.pdf, permanent copy available at http://www.law.washington.edu/wlr/notes/83washlrev449n46b.pdf. For the role of budget analysis in the realm of women's rights, see Debbie Budlender \& Rhonda Sharp, How To Do a GenderSensitive Budget Analysis: Contemporary Research and Practice (1998), available at http://www.Ilbc.leg.bc.ca/Public/PubDocs/docs/360141/AusAIDTr.pdf, permanent copy available at http://www.law.washington.edu/wlr/notes/83washlrev449n46c.pdf. Budget analysis has also been stressed in the context of State reporting obligations on the implementation of economic, social, and cultural rights. See U.N. Econ. \& Soc. Council, Limburg Principles on the Implementation of Economic, Social and Cultural Rights, - 79, U.N. Doc. E/CN.4/1987/17 (Jan. 8, 1987) ("Quantitative information should be included in the reports of States parties in order to indicate the extent to which the rights are protected in fact. Statistical information and information on budgetary allocations and expenditures should be presented in such a way as to facilitate the assessment of the compliance with Covenant obligations. States parties should, where possible, adopt clearly defined 


\section{B. General Principles and the Framing of Disability}

The Convention categorically affirms the social model of disability in relation to persons with disabilities by describing it as a condition arising from "interaction with various barriers [that] may hinder their full and effective participation in society on an equal basis with others" instead of a condition arising from inherent limitations. ${ }^{47}$

Article 3 is fundamental to the crafting of any national-level law and policy framework insofar as it catalogues the Convention's general principles that guide its application and interpretation. These include respect for individual dignity, autonomy, and independence; respect for difference and acceptance of disability as human diversity; nondiscrimination; equal opportunity; complete and meaningful participation; accessibility; sexual equality; respect for children's rights and support of their evolving capabilities. ${ }^{48}$ The inclusion of a generalprinciples article is an innovation that will guide both the interpretation of the entire text of the treaty by its treaty-monitoring body and the development of national law and policy. Given that effective nationallevel law reform likely will not (and should not) manifest in a template approach, the general principles assume special significance.

General principles should also serve as a filter through which discrete pieces of existing law should be run to assess conformity with the object and purpose of the CRPD. As an example, the review of a country's electoral code can be facilitated by using this article to make the following types of assessments:

(1) Independence: Does the election code or regulation provide means for independent voting?

(2) Participation: Does the code provide for voter registration and equal eligibility to stand for office?

(3) Accessibility: Are provisions made for alternative technology and facilitated voting?

targets and indicators in implementing the Covenant.").

47. See CRPD, supra note 1, art. 1. Because these conceptual norms are set forth in the Article of Purpose, it follows that States cannot enter permissible reservations to the normative contents of this Article. See Vienna Convention on the Law of Treaties art. 19, G.A. Res. 2166 (XXI) (Dec. 5 1966), G.A. Res. 2287 (XXII) (Dec. 6, 1967), 1150 U.N.T.S. 331 (prohibiting a state from entering a reservation to a treaty, inter alia, where the "reservation is incompatible with the object and purpose of the treaty").

48. See CRPD, supra note 1 , art. 3 (a); id. art. $3(\mathrm{~d})$; id. art. $3(\mathrm{~b}) ; i d$. art. $3(\mathrm{e}) ; i d$ art. $3(\mathrm{c})$; id. art. $3(\mathrm{f}) ; i d$ art. $3(\mathrm{~g}) ; i d$. art. $3(\mathrm{~h})$ 
(4) Non-Discrimination: Are there impermissible discriminatory provisions which exclude persons with disabilities from participation, for example, by barring otherwise qualified voters with developmental disabilities from voting?

\section{Other Cross-Cutting Articles}

In addition to the general principals article-which plays a fundamental role in ensuring the appropriate domestic incorporation of CRPD standards into law, policy, and programming - the CRPD sets forth other thematic articles of general application to be horizontally integrated across the CRPD. Among these essential building blocks of any national-level law and policy framework are specific articles on the rights of women with disabilities ${ }^{49}$ and children with disabilities. ${ }^{50}$ Other individuals with disabilities subject to multiple forms of discrimination are acknowledged in the Preamble. ${ }^{51}$ Article 8 targets the underlying attitudes causing disability-based discrimination by requiring States Parties to raise public awareness, and provides a list of illustrative measures. ${ }^{52}$ Last, Article 9 seeks to dismantle barriers erected because of discriminatory attitudes by promoting physical, technological, information, communication, economic, and social accessibility ${ }^{53}$ in the public and private sectors. ${ }^{54}$

\section{Substantive Provisions}

The specific substantive articles of the Convention run the gamut of life activities in clarifying, within a disability-specific context, human rights to which all persons are entitled. ${ }^{55}$ These elemental protections include fundamental freedoms such as the right to life, ${ }^{56}$ freedom from

\footnotetext{
49. Id. art. 6

50. Id. art. 7

51. "Concerned about the difficult conditions faced by persons with disabilities who are subject to multiple or aggravated forms of discrimination on the basis of race, colour, sex, language, religion, political or other opinion, national, ethnic, indigenous or social origin, property, birth, age or other status ...."Id. pmbl. (p).

52. Id. art. $8(1)$.

53. Id. art. 9.

54. Id. art. $9(1)$.

55. This dynamic is taken expressly from the CRC. See CRC, supra note 43.

56. CRPD, supra note 1 , art. 10.
} 
torture, ${ }^{57}$ the right to education, ${ }^{58}$ employment, ${ }^{59}$ political participation, ${ }^{60}$ legal capacity, ${ }^{61}$ access to justice, ${ }^{62}$ freedom of expression and opinion, ${ }^{63}$ privacy ${ }^{64}$ participation in cultural life, sports and recreation, ${ }^{65}$ respect for home and family, ${ }^{66}$ personal integrity, ${ }^{67}$ liberty of movement and nationality, ${ }^{68}$ liberty and security of the person, ${ }^{69}$ and an adequate standard of living.

As an aside, although several articles might seem to embody newly created rights, these rights were included in order to direct the means by which other Convention rights are realized. ${ }^{71}$ For example, the articles on living independently, ${ }^{72}$ personal mobility, ${ }^{73}$ and habilitation and rehabilitation ${ }^{74}$ are central if other more historically recognized human rights (like employment) are to be achieved. ${ }^{75}$

\section{E. Monitoring at the National Level}

The monitoring mechanisms and implementation facilitators in the CRPD focus not only on international-level implementation, the chief focus of such measures in earlier human rights treaties, but also extend attention to the national level. This represents a particular innovation for

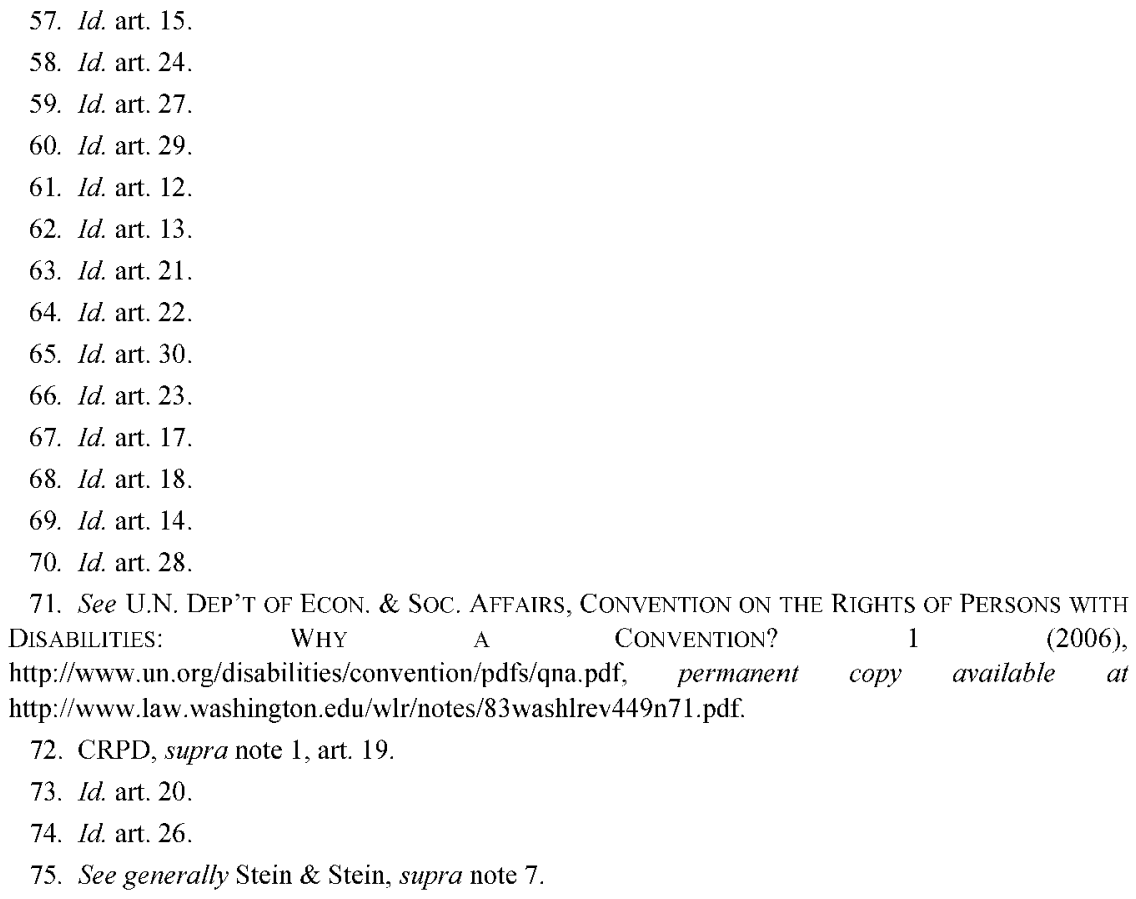


international human rights conventions, although it is a standard feature of environmental and other international agreements. ${ }^{76}$ The attention to the national level is reflective of the increased prominence of NHRIs in United Nations human rights processes in recent years. ${ }^{77}$

Article 33 of the Convention obligates States Parties to "designate one or more focal points" for respective domestic CRPD implementation, ${ }^{78}$ thereby recognizing that implementation of, and compliance with, international human rights treaties are ultimately domestic issues. ${ }^{79}$ States are further required to "give due consideration to the establishment or designation of a coordination mechanism within government to facilitate related action in different sectors and at different levels. ${ }^{\prime 80}$ This latter provision is an explicit acknowledgement by the drafters that responsibility at the national level for ensuring the rights of persons with disabilities extends across a wide range of government sectors; therefore it poses significant coordination and coherency challenges.

Article 33 also requires States Parties to establish and/or support one or more independent mechanisms to "promote, protect and monitor" the

76. See, e.g., International Convention to Combat Desertification in Countries Experiencing Serious Drought and/or Desertification, especially in Africa art. 3(a), 14 Sept. 199433 I.L.M. 1332 (1994); U.N. Framework on Convention Climate Change art. 10, 14(2), May 9, 1992, 31 I.L.M. 849 (1992) (entered into force Mar. 21, 1994); World Health Organization, Framework Convention on Tobacco Control, art. 21, (June 16, 2003), available at http://www.who.int/fctc/text download/en/index.html, permanent copy available at http://www.law.washington.edu/wlr/notes/83washlrev449n76a.pdf; Convention on the Prohibition of the Use, Stockpiling, Production and Transfer of Anti-Personnel Mines and on Their Destruction art. 9, 2056 U.N.T.S. 241, 36 I.L.M 1507 (1997) (Sep. 18, 1997) [hereinafter Mine Ban Treaty], available at http:/www.unog.ch/80256EDD006B8954/(httpAssets)/8DF9CC31A4CA8B32C12571C7002E3F3E/\$file/APLC+English.pdf, permanent copy available at http://www.law.washington.edu/wlr/notes/83washlrev449n76b.pdf.

77. The dialogue on national-level monitoring during the course of the Ad Hoc Committee negotiations was enhanced and significantly influenced by the participation of NHRIs in all sessions of the process. This included the representation of NHRIs on the Working Group of the Ad Hoc Committee.

78. CRPD, supra note 1 , art. 33(1)

79. As such, it is similar to the dual system adopted in the Optional Protocol to the Convention against Torture and Other Cruel, Inhuman or Degrading Treatment or Punishment. The CAT Optional Protocol incorporates a national component in Article 3 requiring State Parties to "set up, designate or maintain at the domestic level one or several visiting bodies for the prevention of torture and other cruel, inhuman or degrading treatment or punishment ...." Optional Protocol to the Convention Against Torture and Other Cruel, Inhuman or Degrading Treatment or Punishment art. 3, G.A. Res. 57/199, U.N. Doc. A/RES/57/199 (Dec. 18, 2002).

80. CRPD, supra note 1 , art. 33(1) 
implementation of the Convention. ${ }^{81}$ It further provides that persons with disabilities and their representative organizations must be "involved and participate fully in the monitoring process." $\$ 2$ However, ultimate effectiveness of DPO representation is largely contingent on how well national, regional, and international disability rights groups organize and advocate in interaction with formal Convention processes.

While the Convention leaves considerable discretion to States when establishing national frameworks for implementation, Article 33 makes broad reference to guidelines for the establishment of national mechanisms. ${ }^{83}$ Nonetheless, it remains unclear what duties a given State Party will allocate to its domestic NHRI (assuming that such an entity exists), and whether States Parties are likely to adopt different approaches. ${ }^{84}$ NHRIs should be regarded as crucial actors in the domestic-level implementation of the Convention, given their typically broad mandates to participate in the drafting of new legislation, review existing legislation, implement education and awareness-raising campaigns, and undertake investigative and quasi-judicial functions. ${ }^{85}$ Their role in this regard is currently encouraged and supported by the International Coordinating Committee of NHRIs, which proactively facilitates ongoing dialogue around the CRPD, by convening both global and regional meetings. ${ }^{86}$

\footnotetext{
81. Id. art. $33(2)$

82. $I d$. art. $33(3)$

83. $I d$ art. $33(2)$
}

84. A proposal in the original draft considered by the Working Group made explicit reference to establishing national mechanisms consistent with the Paris Principles, but it was rejected. The Paris Principles are standards of independence and accountability for National Human Rights Institutions established by the United Nations and enforced through accreditation by the International Coordinating Committee of National Human Rights. Principles Relating to the Status of National Institutions for the Promotion and Protection of Human Rights, G.A. Res. 48/134, U.N. Doc. A/RES/48/134 (Dec. 20, 1993) [hereinafter Paris Principles]. The Office of the High Council for Human Rights (OHCHR), among others, proposed that explicit mention be made of the Paris Principles. See OHCHR, Expert Paper on Existing Monitoring Mechanisms, Possible Relevant Improvements and Possible Innovations in Monitoring Mechanisms, (submission to the 7 th Session of the Ad Hoc Committee), U.N. Doc. A/AC.265/2006/CRP.4, at 20, I 77, available at http://www.un.org/esa/socdev/enable/rights/ahc7docs/ahc7unedchrmonitor.doc, permanent copy available at http://www.law.washington.edu/wlr/notes/83washlrev449n84.pdf. Consequently, it provides substantially less guidance for States in terms of national-level implementation of disability rights.

85. Paris Principles, supra note 84.

86. Global meetings include those convened at Harvard Law School to work out details of the monitoring proposal submitted to the Sixth Ad Hoc Committee session, see Harvard Law School Hosts Planning Session on International Disability Rights, 
U.N. Disability Convention

\section{F. Facilitating National-Level Change}

Under Article 31, States Parties must ensure that their practices regarding disability data and statistics are aligned with the CRPD. ${ }^{87}$ Because disability is a social construct, there is wide divergence in respective national definitions, and therefore prevalence, of disability. ${ }^{88}$ These inconsistencies undermine effective disability policymaking and clearly impede an informed analysis of the comparative statuses of persons with disabilities across countries. ${ }^{89}$ States will need to establish longitudinal data sets whereby they can assess the progress of their own citizens with disabilities over time. Therefore, the effective implementation of this provision will require engagement by national census bureaus-no small task given the abysmal record of such

http:/www.law.harvard.edu/news/2005/12/02_disabilities.php (post date Dec. 2, 2005), permanent copy available at http://www.law.washington.edu/wlr/notes/83washlrev449n86a.pdf, and to discuss implementation more generally. See Webcast: Planning Session on International Disability Rights Public Statements, held by Harvard Law http://www.law.harvard.edu/media/2007/02/16/hrpdisabilityconv.rm. Regional meetings include a September 27, 2007 convening by the Asia Pacific Forum on National Rights Institutions to discuss national-level monitoring and implementation, see Asia Pacific Forum, Now the Real Work Starts: Implementing the UN Disability Convention (2008), available at http:/www.asiapacificforum.net/news/now-the-real-work-starts-implementing-the-un-disabilityconvention.html, permanent available at http://www.law.washington.edu/wlr/notes/83washlrev449n86b.pdf, and a historic public forum held on September 5, 2007 in Seoul, Korea at which Asia Pacific NHRIs discussed monitoring and implementation with representatives of worldwide DPOs. See http://www.asiapacificforum.net/about/annual-meetings/12th-australia-2007/downloads/disabilityissues/APF\%20Report $\% 20-\% 20 D P I \% 20$ Conference.pdf, permanent copy available at http://www.law.washington.edu/wlr/notes/83washlrev449n86c.pdf.

87. CRPD, supra note 1, art. 31(1) ("States Parties undertake to collect appropriate information, including statistical and research data, to enable them to formulate and implement policies to give effect to the present Convention.").

88. Kenya, for example, reports less than one percent of its population as having a disability, compared to twenty percent in New Zealand. Daniel Mont, World Bank, Measuring Disability Prevalence, SP Discussion Paper No. 0706 (March 2007), available at http:/siteresources.worldbank.org/DISABILITY/Resources/Data/MontPrevalence.pdf, permanent copy available at $\mathrm{http} / / \mathrm{www} .1 \mathrm{aw}$. washington.edu/wlr/notes $/ 83$ washlrev $449 \mathrm{n} 88$.pdf.

89. For example, the lack of such empirical data in the United States has been deleterious to reliable conclusions regarding the efficacy of the ADA. See Richard V. Burkhauser \& David C. Stapleton, Introduction to THE DECLINE IN EMPLOYMENT OF PEOPLE WITH DisABILITIES: A POLICY PuzzLE 2 (David C. Stapleton \& Richard V. Burkhauser eds., 2003); NATIONAL COUNCIL ON DisABILITY, THE IMPACT OF THE AMERICANS WITH DisABILITIES ACT: ASSESSiNG THE PROGREsS TOWARD ACHIEVING THE GOALS OF THE ADA 23 (2007), available at http:/www.ncd.gov/newsroom/publications/2007/pdf/ada_impact_07-26-07.pdf, permanent copy available at $\mathrm{http}: / / \mathrm{www}$.law.washington .edu/wlr/notes/83washlrev 449 n 89 .pdf. 
agencies in designing and implementing disability data collection. ${ }^{90}$

The Convention expressly recognizes that international cooperation aids national efforts to effectively implement States Parties' obligations. $^{91}$ States Parties to the Convention are to cooperate internationally through partnerships with other States, and/or with relevant international and regional organizations and civil society in support of national measures to give effect to the CRPD. ${ }^{92}$ Article 32 identifies a range of measures that States can take within the framework of international cooperation. Measures include "capacity building, including through the exchange and sharing of information, experiences, training programs and best-practices"; ${ }^{93}$ the facilitation of research programs and of access to scientific knowledge; ${ }^{94}$ and technical and economic assistance, including the facilitation of access to accessible and assistive technologies. ${ }^{95}$

Importantly, Article 32 makes it clear that all international cooperation efforts, including international development programs, should fully include persons with disabilities and be accessible. ${ }^{96}$ Specifically, all States Parties are required to ensure that all aspects of their aid programs completely integrate persons with disabilities, from design through implementation and evaluation. ${ }^{97}$ The Conference of States Parties would be an ideal vehicle to monitor this requirement, as well as a forum for sharing best practices in inclusive development in various sectors. $^{98}$

90. The Washington Group has responded to the failure of national census bureaus across the world to include disability questions in national census exercises by formulating questions designed to address this gap. See National Center for Health Statistics, Washington Group on Disability Statistics, REVISED Census Questions on Disability Endorsed by the Washington Group, http://www.cdc.gov/nchs/about/otheract/citygroup/products/meeting6/REVISED\%20WG\%20Short $\% 20$ Measure\%20on\%20Disability.doc, permanent copy available at http://www.law. washington.edu/wlr/notes/83washlrev449n90.pdf.

91. CRPD, supra note 1, art. 32(1) ("States Parties recognize the importance of international cooperation and its promotion, in support of national efforts for the realization of the purpose and objectives of the present Convention, and will undertake appropriate and effective measures in this regard, between and among States and, as appropriate, in partnership with relevant international and regional organizations and civil society, in particular organizations of persons with disabilities.").

92. Id. art. $32(1)$.

93. Id. art. 32(1)(b).

94. Id. art. $32(1)(\mathrm{c})$.

95. Id. art. $32(1)(\mathrm{d})$.

96. Id. art. 32 .

97. Id.

98. This has proved a useful practice in the Mine Ban Treaty implementation process. Regular 
The foregoing analysis outlines the comprehensive framework developed by the drafters of the Convention through which States Parties may begin to achieve domestic-level change. This transformation takes place not only through processes of domestic law and policy change, but more broadly through innovative programming and through processes of socialization and acculturation. What follows in Part III charts the challenges and opportunities for operationalizing the rights regime of the CRPD through national-level change processes.

\section{OPERATIONALIZING HUMAN RIGHTS: THE CHALLENGES AND OPPORTUNITIES OF REALIZING THE CRPD AT THE NATIONAL LEVEL}

The process of translating the CRPD into national-level action and advocacy is already underway, presenting unique opportunities for positive change, and at the same time, revealing major challenges in realizing the Convention's promise. For implementation to be effective, disability advocates need to engage in a comprehensive human rights practice that encompasses national disability-law adoption and reform, as well as strategic litigation inspiring court applications of CRPD rights. These activists and their allies must also employ a range of other approaches and techniques that are contemplated by a full and integrated reading of the CRPD. These include, inter alia, the familiar techniques of lawmaking and policymaking as well as strategies implementing the inclusive development mandate of the Convention, facilitating the expressive value of the CRPD through education and empowerment at the individual and community level, strengthening the organizational and advocacy capacity of DPOs, and forging strong links among and beyond the disability community and NHRIs. We discuss each of these in turn, beginning with standard practices of constitution-building and legislative reform and progressing to less common (but equally valuable) means of incorporating change into domestic legal interpretation and foreign assistance programs.

meetings of States Parties have provided an important forum for reporting and sharing best practices in Mine Ban Treaty implementation, including, for example, expenditures on victim-assistance programming. For more on Mine Ban Treaty implementation and meetings of States Parties, see the International Campaign to Ban Landmines Treaty Meetings website, available at http:/www.icbl.org/treaty/meetings (last visited Nov. 16, 2008), permanent copy available at http:/www.law.washington.edu/wlr/notes/83washlrev449n98.pdf. See also Mine Ban Treaty, supra note 76 . 


\section{A. Human Rights and Constitution-Building Processes}

Where applicable, disability advocates have the opportunity to harness constitutional-reform processes and transpose international human rights standards into the constitutional frameworks. ${ }^{99}$ Such processes are as important for their visibility-enhancing and constituency-broadening potential as for their capacity to lay the foundation for a solid legal framework for disability rights work. ${ }^{100}$ The experiences of constitutional reform in Uganda and South Africa serve as salient examples of how marginalized constituencies can foment their political visibility and power to strategic advantage. In both countries, DPOs raised their voices, resulting in both constitutional recognition of their human rights and a strengthening of their constituency as a potent political force. ${ }^{101}$ Ongoing constitutional-law reform in both Nepal and Zambia has DPOs working to ensure that drafting processes effectively include their voices. ${ }^{102}$ Constitution-building processes like these offer both substantive and procedural change. When constitutions incorporate a disability rights perspective, they cement rights that may already have existed but were neglected, much as the CRPD does on the international level. Engaging persons with disabilities in these processes develops their civil-society capacities and establishes their place in future reform efforts.

This advocacy fosters the building of stronger and more engaged

99. This may be achieved through various mechanisms, including through the explicit recognition of disability as a prohibited ground of discrimination in a non-discrimination clause or through the incorporation of international human rights standards into the constitutional framework.

100. For an excellent treatment of human rights and constitutions, see Thomas Buergenthal, Modern Constitutions and Human Rights Treaties, 36 COLUM. J. TRANSNAT'L L. 211 (1997).

101. Jeff Radebe, Keynote Address at the Disabled People South Africa Conference: Ten Years of Democracy-The Current and Future Status and Role of People with Disabilities, (Mar. 12, 2004), available at http:/www.polity.org.za/article.php?a_id=48262, permanent copy available at http://www.law.washington.edu/wlr/notes/83washlrev449n101a.pdf; Maria Kangere, Disability in Development: The Uganda Experience, (Conference Paper: Inclusion of Disability in Dutch Development Cooperation Policy and Practice, 2003), available at http:/www.dedd.nl/data/1067944239230_Development\%20in\%20Disability\%20paper\%20(Maria\% 20Kangere).pdf, permanent copy available at http://www.law.washington.edu/wlr/notes/83washlrev449n101b.pdf.

102. See, e.g., NepalNews.com, NFDN Demands Equal Opportunity for Persons with Disabilities (June 7, 2006), available at hitp/www.nepalnews.com/archive/2006/jun/juno7/nows 10.php, permanent copy available at http:/www.law.washington.edu/wlr/notes/83washlrev449n102.pdf; Trternational Labour Organization. Employnent of Persons wh Disabilities: The lwnact of Legislation, Report of a Technical Consulation, THE GLADNET COLLECTON 12 (2002) ("In Zambia, the Persons with Disabilities Act No. 33 of November 1996 is a good example of antidiscrimination law[.]") 
disability rights coalitions, increases the visibility of disability groups, and fosters linkages between disability groups and other civil-society actors and allies. The challenge of engaging effectively in such processes is substantial for disability communities worldwide, much as all marginalized communities face considerable barriers in securing social, political, and legal change for their constituencies. Coalition work is fraught with divisions, and organizational governance and capacity deficits further undermine the effectiveness of advocacy efforts, notwithstanding progress in the strengthening of disability advocacy in many countries. ${ }^{103}$ Despite these challenges, a constitution-building process provides a focal point for coalition-building and the honing of advocacy techniques that can be strengthened and harnessed for longterm change in new democracies.

\section{B. Human Rights and National Legislative Action}

Ensuring the domestic incorporation of human rights law through legislative change-long a darling of human rights action and advocacy - is undoubtedly an important step in bringing international human rights law home. This is so not only due to the legislative result, but also because participating in the reform exercise has the potential to generate a stronger constituency and foster governmental awareness.

Law reform that takes place within a robust democratic process will foment relationship-building among disability advocates and other civilsociety allies. It will also create potential entry points for advocacy directed at monitoring governmental implementation. The CRPD will trigger unprecedented national-level engagement with disability law and policy among States Parties. The CRPD will also encourage the vast majority of States that have yet to ratify the Convention to develop or substantially reform their domestic, legal, and social policies regarding persons with disabilities. ${ }^{104}$ While the Convention will imbue lawmaking and law reform with a vigor that has had no parallel in modern human rights practice, $^{105}$ it likewise presents considerable challenges for

103. The inability of the International Disability Alliance to build a strong, sustained, and wellresourced coalition is replicated at the domestic level where impairment-specific organizations traditionally provide services in isolation from each other and rarely if ever engage in effective coalition work. Cf. Janet E. Lord, Mirror, Mirror on the Wall: Voice Accountability and NGOs in Human Rights Standard Setting, 5 SETON HALL J. DIPL. \& INT'L REL. 93 (2004).

104. The authors, for example, have worked on law reform in several countries that have yet to ratify the CRPD, including Korea, Laos, Russia, and Vietnam.

105. As noted by the President of the General Assembly on the day of the CRPD's adoption, the 
effective national-level implementation through the mechanism of legislative action. ${ }^{106}$

States' engagement with their own domestic-level disability laws and policies will necessarily manifest on at least three interrelated levels. To begin with, each State must decide whether it will ratify the CRPD, and then adjust its own national-level schemes (including the designation of focal points for monitoring and implementation ${ }^{107}$ ) accordingly; ${ }^{108}$ finetune its national framework prior to ratification; ${ }^{109}$ or adopt some transitional measure. ${ }^{110}$ Next, each State must assess its individual sociolegal circumstances and determine how to most expediently balance antidiscrimination prohibitions with equality measures. ${ }^{111}$ Last, each

treaty's consensus acceptance "is a great opportunity to celebrate the emergence of comprehensive guidelines the world so urgently needs." President of the United Nations General Assembly, Statement at the Adoption of the Convention on the Rights of Persons with Disabilities (Dec. 13, 2006), available at http:/www.un.org/ga/president/61/statements/statement $20061213 . \mathrm{shtml}$, permanent copy available at $\mathrm{http} / /$ www.law.washington.edu/wlr/notes/83washlrev449n105.pdf.

106. To illustrate, Morocco has no comprehensive disability law. Legislation dating to 1982 applies to only a few limited rights with respect to persons with visual impairments, but not to persons with other types of disabilities. The Convention process, in which the Moroccan government and NGOs played major roles, has promoted national-level planning and prompted national-level legislative reform to remedy major gaps. See Secrétariat a'Etat Chargé de la Famille, de l'Enfance et des Personnes Handicapées, Programme National de Réadaptation a Base Communitaire au Profit des Personnes Handicapées 2006-2008 (2006).

107. See CRPD, supra note 1, art. 33(1) (obligating States Parties to "designate one or more focal points within government for matters relating to the implementation of the present Convention"); art. 33(2) (requiring States Parties to "maintain, strengthen, designate or establish ... one or more independent mechanisms ... to promote, protect and monitor implementation" of the CRPD); and art. 33(1) (further requiring States to "give due consideration to the establishment or designation of a coordination mechanism within government to facilitate related action in different sectors and at different levels").

108. For example, Jamaica, the first State to ratify the Convention, has not acted to align its domestic legal framework with the Convention and remains a disability rights violator in a number of other areas. See generally U.S. Dep't of State, Country Reports on Human Rights Practices: Jamaica (2007), available at http:/www.state.gov/g/drl/rls/hrrpt/2006/78897.htm, permanent copy available at $\mathrm{http} / /$ www.law.washington.edu/wlr/notes/83washlrev449n108.pdf.

109. New Zealand, a leading country in the treaty negotiations, has some notably progressive domestic disability practices, but its legal framework remains underdeveloped in the comprehensive sense mandated by the Convention. See Anne-Marie Mooney Cotter, THIS ABILITY: AN INTERNATIONAL LEGAL ANALYSIS OF DISABILITY DISCRIMINATION 100-20 (2007).

110. Mexico's Senate, for example, ratified the CRPD but made a declaration that it would not apply Article 12 because its domestic law on legal capacity exceeded the Convention's requirements. After well-publicized statements by two experts, the Senate acquiesced to reconsider its position. See Katia D'Artigues, Mexico, Farol de la Calle, ¿Oscuridad en Casa?, EL UNIVERSAL, Oct. 26, 2007, at A19 (describing the critiques offered by Professors Gerard Quinn and Michael Stein to the General Assembly of Human Rights Institutions of the Americas).

111. Take, for example, the E.U. Framework Directive, prohibiting discrimination in employment 
State must resolve unsettled interpretations of existing disability-related principles (for instance, access to justice) ${ }^{112}$ and also grapple with Convention rights not previously endorsed in domestic law (such as a right to mobility). ${ }^{113}$

Law reform is a continual process in most countries. Given the multisectoral nature of disability, implementing the legislative change obligations of the CRPD is likely to be a complex process. Additionally, the fragmented nature of disability-related legislation will pose further challenges. This presents considerable difficulties for governments and disability advocates alike. As a first step, it stands to reason that the framework provided by Article 33 should be secured prior to full-scale review of existing laws and amendments or development of new legislation to bring the CRPD into domestic law. ${ }^{114}$ A fully compliant legislative-review exercise, as contemplated by Article 4 of the Convention requires more than the adoption of general disability rights legislation. ${ }^{115}$ It needs to include, for example, a thorough review of the existing electoral code and its implementing regulations as part and parcel of Article 29 implementation. ${ }^{116}$ Thus, when an electoral code or election commission regulations are being reformed or developed, disability groups should participate to ensure that the implications of CRPD Article 29 are secured. ${ }^{117}$ Such participation can be seen in the

on the basis of disability. See Council Directive 2000/78/EC, art. 12, 2000 O.J. (L 303) 17 (EU). The Directive requires individual employers to take "appropriate measures" to provide reasonable accommodations. It is neutral, however, as to whether Member States may support disabled employment through "specific measures" (i.e., equity modifiers). Id. art. 7. An undetermined issue is how Member States with pre-existing programs - such as the employment quota system operated in Germany-will respond to the Directive's purely antidiscrimination mandate. The same dynamic is at play in Japan, where the government is under pressure by disability rights groups to supplement or supplant the existing quota system with anti-discrimination laws.

112. See generally Tennessee v. Lane, 541 U.S. 509 (2004) (holding that one particular individual had a right to physically access one particular court, but leaving open the question of whether any other persons with disabilities could gain relief when denied access to other justice elements, for example, as witnesses or jurors).

113. CRPD, supra note 1, art. 20 ("States Parties shall take effective measures to ensure personal mobility with the greatest possible independence for persons with disabilities . ...").

114. Id. art. 33 .

115. Id. art. 4

116. Id. art. 4(3) ("In the development and implementation of legislation and policies to implement the present Convention, and in other decision-making processes concerning issues relating to persons with disabilities, States Parties shall closely consult with and actively involve persons with disabilities, including children with disabilities, through their representative organizations.").

117. $I d$. art. 29 
International Foundation for Electoral Systems' work in Liberia and elsewhere in Africa and the Middle East. ${ }^{118}$ In the context of implementing the right to health, ${ }^{119}$ Nora Groce has demonstrated in a World Bank study on HIV/AIDS and disability that the needs of people with disabilities must be included in national AIDS strategies and reflected in programming to ensure that disabled people are reached. ${ }^{120}$ This would require, among other things, training health-care professionals and health-education workers in methods of outreach to the disability community. ${ }^{121}$

Effective legislative change is a complex process that requires far more than the application of a superficial "model law" template for CRPD implementation. While it is tempting to prescribe the one-sizefits-all approach to help advance Convention implementationespecially if the domestic-law framework in question is a relatively blank slate - such efforts are sure to disappoint. Such a methodology also fundamentally misses the point of how a human rights convention is supposed to accomplish change. The CRPD provides a framework within which a country's disability-law framework may be assessed and particularized in accordance with a given legal system and culture.

\section{Human Rights Standards as Domestic Interpretive Devices}

When demonstrating the relevance of international law at the domestic level beyond direct court invocations of human rights norms, scholars have catalogued cases in which courts have utilized human rights standards indirectly, showing that courts have done so with significant- though not dispositive-effect. ${ }^{122}$ The courts' approach, termed "creeping monism" by

\footnotetext{
118. See Int'1 Found. for Electoral Sys., http://www.electionaccess.org (last visited Sept. 24, 2008), permanent copy available at http:/www.law.washington.edu/wlr/notes/83washlrev449n1 18.pdf.

119. CRPD, supra note 1 , art. 25.

120. NORA GROCE ET AL., GUIDELINES FOR INCLUSION OF INDIVIDUALS WITH DISABILITY IN HIV/AIDS OUTREACH EFFORTS (2006), http://siteresources.worldbank.org/DISABILITY/Resources/2806581161026944612/HIVGuidelinesENG.doc, permanent copy available at http://www.law.washington.edu/wlr/notes/83washlrev449n120.pdf.

121. Id.

122. See Harold Hongju Koh, The 1998 Frankel Lecture: Bringing International Law Home, 35 Hous. L. REV. 623 (1998); Ralph G. Steinhardt, The Role of International Law as a Canon of Statutory Construction, 43 VAND. L. REV. 1103 (1990); Melissa A. Waters, Creeping Monism: The Judicial Trend Toward Interpretative Incorporation of Human Rights Treaties, 107 COLUM. L. REV. 628 (2007)
} 


\section{U.N. Disability Convention}

one observer, ${ }^{123}$ spawns the application of international human rights standards through various forms of judicial recognition and relevance. ${ }^{124}$ Carefully catalogued by Melissa Waters in her study of the process by which the International Covenant on Civil and Political Rights has been received by courts in five common-law jurisdictions, ${ }^{125}$ courts may take human rights standards into account to (1) bolster reasoning based principally on domestic-law sources; ${ }^{126}$ (2) interpret domestic statutes consistently with human rights standards; ${ }^{127}$ (3) update the common law; ${ }^{128}$ (4) contextually interpret a nation's bill of rights; and (5) apply a canon of constitutional interpretation that construes domestic constitutions in alignment with international human rights law. ${ }^{129}$

There is ample evidence that courts will consult human rights standards

123. This term was coined by Waters to characterize a judicial trend in some common-law systems to take human rights norms into account notwithstanding the absence of implementing domestic legislation. See Waters, supra note 122 , at 628 .

124. This trend contrasts markedly with the traditional approach taken by courts in other common-law jurisdictions, and British Commonwealth countries in particular, that declines to give effect to treaties absent express implementing legislation. This approach is consistent with a dualist, as opposed to monist orientation. Id. at 628 (noting the historic entrenchment of dualism in British Commonwealth jurisdictions).

125. According to Waters' theory, international human rights standards provide additional support for a court's reasoning regarding the interpretation of a domestic law. Waters, supra note 122, at 654; see also Steinhardt, supra note 122, at 1110; Melissa A. Waters, Mediating Norms and Identity: The Role of Transnational Judicial Dialogue in Creating and Enforcing International Law, 93 GEO. L.J. 487 (2005).

126. Waters, Mediating Norms, supra note 125, at 569-70 (referencing the U.S. Supreme Court's willingness to use international law to confirm the reasonableness of decisions based in domestic law)

127. Id. at 509 ("But through judicial interpretation by both national and supranational tribunals over the past two decades, the prohibition on cruel or inhuman punishment has evolved to encompass real limitations on the death penalty. Using comparative analysis, courts have interpreted this norm to progressively limit or even to abolish domestic statutes permitting the use of the death penalty."); see also William A. SChabas, The DeAth Penalty as Cruel Treatment and TORTURE 13-56 (1996).

128. Waters, Mediating Norms, supra note 125 , at 502 ("The co-constitutive process is an iterative one in which various 'law-declaring fora'-domestic courts, legislatures, foreign ministries, and the like-articulate and champion domestic norms at the transnational level. Domestic norms thus become part of the international legal discourse, and are translated, modified, diffused and dispersed through various kinds of transnational and transgovernmental channels. These norms, modified to a greater or lesser extent by the international legal discourse, return to the domestic fora to be internalized into domestic law and to further shape and re-shape domestic societal and cultural norms."); see also Curtis A. Bradley \& Jack L. Goldsmith, Customary International Law as Federal Common Law: A Critique of the Modern Position, $110 \mathrm{HARV}$. L. REV. $815,838-42$ (1997).

129. Waters, Mediating Norms, supra note 125 , at 509. 
within non-binding instruments or non-ratified treaties in order to determine the content of customary international law. ${ }^{130}$ In this way, human rights are building blocks in the construction of domestic human rights regimes. The implications of domestic incorporation through interpretive judicial process in the case of the CRPD is especially poignant in those States with a demonstrated practice of taking human rights standards into account, including, for example, key drafters of the Convention: Australia, New Zealand, and Canada. Even in the face of ratification and incorporation through implementing legislation, courts can give weight to non-binding disability instruments such as the U.N. Standard Rules, ${ }^{131}$ or treaty obligations modified by reservations, declarations, and understandings. ${ }^{132}$ These mechanisms suggest strategic advocacy approaches through which disability advocates can serve as transnational norm entrepreneurs helping to transpose CRPD norms in domestic legal systems. ${ }^{133}$

\section{The Constitutive and Educative Effects of Human Rights Standards}

Beyond the formal mechanisms which incorporate human rights standards at the domestic level are processes that foster social transformation, utilizing human rights norms as primary drivers. While these mechanisms have been largely ignored in the international law literature, international relations scholars have recognized that human rights norms have power to work change through non-legal

130. See, e.g., Rodriquez-Fernandez v. Wilkinson, 654 F.2d 1382, 1388 (10th Cir. 1981) (citing both the American Convention on Human Rights (American Convention) and the Universal Declaration of Human Rights (UDHR) as evidence of the customary-law prohibition of prolonged arbitrary detention); Filartiga v. Pena-Irala, 630 F.2d 876, 883-85 (2d Cir. 1980) (taking account of the American Convention and the International Covenant on Civil and Political Rights (ICCPR), inter alia, to determine the customary prohibition against torture); Forti v. Suarez-Mason, 672 F. Supp. 1531, 1542 (N.D. Cal. 1987) (citing the UDHR, American Convention, and ICCPR to assert the existence of a customary rule prohibiting summary execution), reh'g granted in part and denied in part, 694 F. Supp. 707 (N.D. Cal 1988); Laureau v. Manson, 507 F. Supp. 1177, 1187-89 \& n.9 (D. Conn. 1980) (citing the U.N. Minimum Standard Rules Governing the Treatment of Prisoners), modified, 651 F.2d 96 (2d Cir. 1981), aff'd in part and modified in part, 651 F.2d 96 (2d Cir. 1981). For collections of American case law citing to international human rights standards, see RICHARD Lillich, INTERNattonal Human Rights Instruments 440 (1986); JORdan J. PAUst, INTERNATIONAL LAW AS LAW OF THE UNITED STATES (1996).

131. Standard Rules on the Equalization of Opportunities for Persons with Disabilities, G.A. Res. 48/96, U.N. GAOR, 48th Sess., Supp. No. 49, at 202, U.N. Doc. A/48/49 (Mar. 4, 1994).

132. See generally Ryan Goodman, Human Rights Treaties, Invalid Reservations, and State Consent, 96 AM. J. INT'L. L. 531 (2002).

133. Koh, supra note 17 , at 2612 . 
mechanisms. ${ }^{134}$ Such an approach recognizes processes by which human rights trigger belief changes by providing information to societies about the human rights ideas with the attendant effect of serving as educational tools for altering social mores. ${ }^{135}$ These notions comprehend human rights law as a process ${ }^{136}$ through which actors' identities and interests are shaped and reconstituted. ${ }^{137}$ Viewed this way, human rights are instruments that are capable of, in their effective application, recasting negative social constructions into rights-aligned perspectives and enunciating specific protections toward the full enjoyment of human rights.

The text of the CRPD recognizes, at least in part, the role that human rights principles may play in generating social change and in reconstructing ideas that are antithetical to the full realization of disability rights. States Parties are tasked with an affirmative duty to alter social norms regarding persons with disabilities, which includes the responsibility to eviscerate harmful stigmas and stereotypes and promote positive imagery. ${ }^{138}$

134. KECK \& STKKINK, supra note 21 , at 30 (providing case studies of human rights campaigns that worked social change through transnational advocacy networks, or communicative structures whose members are primarily motivated "by shared principled ideas or values") (italics in original). For a rare account by an international legal scholar of the importance of social process to work change well beyond the narrow rule of law realm, see Narula, supra note 20, at 257. Narula provocatively poses the question "whether the law can be a vehicle for social change, or does it simply divert attention away from the social condition it masks and act as a safety-valve to diffuse pressure for real reform ...."Id. at 335. In the context of caste-based discrimination, she calls for a "dismantling of the caste-based hierarchical mindset[,]" which cannot be achieved through lawreform efforts alone. $I d$. at 258 . Both of these insights resonate as the process of domestic change gains momentum following the CRPD's entry into force as well as its on-going, widespread ratification

135. For an account of the expressive-law value of human rights treaties, see Alex Geisinger \& Michael Ashley Stein, A Theory of Expressive International Law, 60 VAND. L. REV. 77 (2007), and Alex Geisinger \& Michael Ashley Stein, Rational Choice, Reputation, and Human Rights Treaties, 106 U. MiCH. L. REV. 1129 (2008). For the application of these ideas to the process by which the CRPD was negotiated, see Janet E. Lord, Normative Landscaping: Power and Norms within Human Rights Law-Making Processes (Feb. 2005) (unpublished manuscript) available at http://www.law.washington.edu/wlr/notes/83washlrev449n135.pdf.

136. On the understanding of international law as a process, see generally ROSALYN HIGGINS, PROBLEMS AND PROCESS: INTERNATIONAL LAW AND HOW WE USE IT (1994).

137. See Christian Reus-Smit, Constructivism, in THEORIES OF INTERNATIONAL RELATIONS 218 (2001) (noting that "[i]nstitutionalized norms and ideas" can "condition what actors' [sic] consider necessary and possible, both in practical and ethical terms"); Alexander Wendt, Constructing International Politics, 20 INT'L SEC. 73 (1995) (positing that systems of shared ideas, beliefs and values work to influence social and political action within and across multilateral law-making processes).

138. See, e.g., CRPD, supra note 1, art. 8 (requiring States Parties "to adopt immediate, effective 
During the CRPD negotiation process, a linguistic shift transpired among States representatives, moving away from medical and charitymodel terminology toward a social model of rights-based taxonomy. For instance, an early intervention made by Nigeria contrasted persons with disabilities with "normal people," later session called on delegates to refrain from using inappropriate language when referencing persons with disabilities. ${ }^{140}$

In this respect, the CRPD has also generated an array of tangible benefits. These include raising the general public's awareness about the human rights of persons with disabilities; highlighting historic and continued abuses of those rights; further developing the knowledge base of States Parties through the requirement of consultation with domestic and international DPOs and non-governmental organizations (NGOs); providing the impetus for extensive programmatic developments, including foreign-assistance schemes; and improving data collection.

The Convention has expressive value insofar as it signals the global community's recognition that persons with disabilities have equal dignity, autonomy, and worth. ${ }^{141}$ The CRPD can serve to precipitate belief changes by providing information to societies about the rights of persons with disabilities. ${ }^{142}$ As such, its potential for altering social mores may be effectively realized through the Convention's provisions

\footnotetext{
and appropriate measures .... [t] o raise awareness throughout society, including at the family level, regarding persons with disabilities, and to foster respect for the rights and dignity of persons with disabilities ...."). For a practical application of human rights education and awareness raising, see JANET E. LORD ET AL., HUMAN RIGHTS. YES! (2007), available at http:/wwwl.umn.edu/humanrts/edumat/hreduseries/TB6/pdfs/Manuals/final_pdf_default_withcover.pdf, permanent copy available at http://www.law.washington.edu/wlr/notes/83washlrev449n138.pdf.

139. Oral Intervention to the Ad Hoc Committee by Representative from Nigeria to the Ad Hoc Committee, Disability Negotiations Daily Summary Vol. 1, \#7 (Aug. 6, 2002), http://www.worldenable.net/rights/adhocmeetsumm07.htm, permanent copy available at http://www.law.washington.edu/wlr/notes/83washlrev449n139.pdf.

140. Oral Intervention to the Ad Hoc Committee by Representative from South Africa to the Ad Hoc Committee, Disability Negotiations Daily Summary, Vol. 1, \#4 (Aug. 1, 2002), http://www.worldenable.net/rights/adhocmeetsumm04.htm, permanent copy available at http://www.law.washington.edu/wlr/notes/83washlrev449n140.pdf.

141. Expressive law explores the process whereby legal instruments affect preferences and behavior by altering social perceptions and conventions. See generally Alex Geisinger, A Belief Change Theory of Expressive Law, 88 IOWA L. REV. 35 (2002). For a literature review of expressive law, see Michael Ashley Stein, Under the Empirical Radar: An Initial Expressive Law Analysis of the ADA, 90 VA. L. REV. 1151 (2004).

142. For an account of the expressive-law value of human rights treaties, see Geisinger \& Stein, supra note 135
} 
supporting its use as an educational tool. ${ }^{143}$ In this respect, the CRPD's discussion of the unnecessary and amenable nature of the historical exclusion of persons with disabilities across societies can serve a vital function beyond the particular domestic-law implementation of its substantive obligations in law and policy. ${ }^{144}$

\section{E. Rights-Based Foreign-Assistance Programs}

There are a variety of mechanisms by which human rights shape foreign policy. ${ }^{145}$ More specifically for present purposes, human rights can have both domestic and extra-territorial effect in shaping first the design and then the implementation of foreign-assistance programming.

The CRPD is the first core human rights convention to explicitly call upon States Parties to reform their development-assistance programs to include people with disabilities. ${ }^{146}$ Thus, considerable effort must be taken to ensure that donor governments and recipient developing countries adhere to the mandate of inclusive development. This is unlikely to be achieved through the vehicle of national disability legislative reform, but instead must be implemented through the adoption and careful monitoring of development policies.

The CRPD should prompt donor governments to ensure that their development-assistance programs include persons with disabilities, thereby supporting the social integration of persons through inclusive development programming. ${ }^{147}$ Current development practices by and

143. See, e.g., CRPD, supra note 1, art. 8 (requiring States Parties "to adopt immediate, effective and appropriate measures ... [t]o raise awareness throughout society, including at the family level, regarding persons with disabilities, and to foster respect for the rights and dignity of persons with disabilities ...."). In this regard, the tools of human rights education may assume an important role in fostering the expressive value of the CRPD. See, e.g., LORD ET AL., supra note 138.

144. CRPD, supra note 1, pmbl. ( $\mathrm{k}$ ) (expressing concern that "persons with disabilities continue to face barriers in their participation as equal members of society and violations of their human rights in all parts of the world").

145. The literature on human rights and foreign policy generally is voluminous. See Buergenthal, Shelton \& Stewart, supra note 13, at 347-401; Julie A. MERTus, Bait AND Switch: Human Rights And U.S. Foreign POlicy (2d ed. 2008); Mark L. Schneider, A New Administration's New Policy: The Rise to Power of Human Rights, in HuMAN RightS AND U.S. Foreign Policy, Principles And Applications 3 (Peter G. Brown \& Douglas Maclean eds., 1979); David Weissbrodt, Human Rights Legislation and U.S. Foreign Policy, 7 GA. J. INT"L \& COMP. L. 231 (1977).

146. See CRPD, supra note 1 , art. 32 .

147. Id. art. 32(1)(a) (requiring States Parties to "undertake appropriate and effective measures" in making sure that "international cooperation, including international development programmes, is inclusive of and accessible to persons with disabilities"). 
large exclude people with disabilities, ${ }^{148}$ and thereby increase alreadywide equity gaps between disabled and mainstream populations. ${ }^{149}$ The CRPD creates a framework for international cooperation to be implemented in accordance with its general principles including, for example, the principles of non-discrimination and participation. Aid for inclusive development can improve the accessibility in developing countries of the physically constructed environment by requiring that technical assistance, development aid, and humanitarian efforts by States Parties conform with the Convention's general principles, as well as to the policies and procedures that aid-sponsored programs support.

Trenchantly, increasing social participation helps make persons with disabilities more visible ${ }^{150}$ and facilitates their enjoyment of other fundamental rights. ${ }^{151}$ The CRPD's provisions can, therefore, lessen the identification of persons with disabilities as "other," 152 promote greater familiarity with the group, ${ }^{153}$ and bring communities closer to the Vienna Declaration's oft-recited refrain that human rights are "indivisible and

\footnotetext{
148. See Bill Albert, Is DisABility ReAlly on the Development Agenda?: A Review of OfFICIAL DISABILITY POLICIES OF THE MAJOR GOVERNMENTAL AND INTERNATIONAL DEVELPMENT AGENCIES $\quad 7$ (Sept. http://www.disabilitykar.net/pdfs/disability_on_the_agenda.pdf, permanent copy available at http://www.law.washington.edu/wlr/notes/83washlrev449n148.pdf (detailing the historical disregard of inclusive development practice among donor governments in their development assistance programming); see also Amy T. Wilson, The Effectiveness of International Development Assistance from American Organizations to Deaf Communities in Jamaica, 150 AM. ANNALS OF THE DEAF 292, 298 (2005) (describing how USAID, in working "on behalf of" deaf-based development, did not work in conjunction with the local deaf community).

149. See generally BRITISH COUNCIL OF DISABLEd PEOPLE's INT'L COMM., IMPRoving DFID'S ENGAGEMENT WITH THE UK DISABILITY MOVEMENT 4 (2005), http:/Www.dfid.gov.uk/pubs/files/bcodp-dfid-disability.pdf, permanent copy available at http://www.law.washington.edu/wlr/notes/83washlrev449n149.pdf.

150. See QUINN \& DEGENER, supra note 23, at 23 ("People with disabilities were often virtually invisible citizens of many societies," and "have been marginalized in nearly all cultures throughout history."); see also MARK C. WEBER, DISABILITY HARASSMENT 6 (2007) ("Lack of daily contact at a level of true equality with persons with disabilities promotes and constantly reinforces stereotypes.").

151. NAT'L COUNCIL ON DISABILITY, THE IMPACT OF THE AMERICANS WITH DISABILITIES ACT: Assessing the Progress Toward ACHIEving the GoAls of THE ADA (July 26, 2007), http://www.ncd.gov/newsroom/publications/2007/pdf/ada_impact_07-26-07.pdf, permanent copy available at http://www.law.washington.edu/wlr/notes/83washlrev449n151.pdf.

152. This is a standard sociological argument. The classic treatment is ERVING GOFFMAN, STIGMA: NOTES ON THE MANAGEMENT OF SPOILED IDENTITY 5 (1963) (asserting that stigma manifests when "we believe the person with a stigma is not quite human").

153. For an argument on this ground in favor of employing greater numbers of persons with psycho-social disabilities, see Michael E. Waterstone \& Michael Ashley Stein, Disabling Prejudice, 102 NW. U. L. REV. 1352 (2008).
} 
interdependent and interrelated." 154 The promise of the CRPD as a tool for inclusive development offers challenges, as well as opportunities, for responsible, rights-based development programming in all sectors, including democracy and governance, health, education, and the environment.

\section{CONCLUSION}

The CRPD is perhaps the most far-reaching of human rights instruments insofar as it outlines a framework for its obligations to take root not only in law, but more broadly, in society. To realize its purposes, persons with disabilities and their allies must look beyond human rights practice as legislative advocacy or court-driven action and engage deeply in the full range of disability advocacy contemplated by the CRPD, including participatory education, human rights culturebuilding and well-coordinated and well-conceived coalition work. Likewise, the foreign-assistance community must understand that social change requires sustained commitments and the engagement of the disability community to ensure inclusive, rights-oriented programming that moves well beyond top-down law reform or one-off judicial training exercises. Finally, scholars concerned with domestic processes where international law takes root should expand the parameters of their projects to go beyond proving the pull of international law through domestic court applications or ratification procedures. They should instead concern themselves with a more nuanced and interdisciplinary exercise that sees human rights law as a socially transformative process of change and culture-building.

154. World Conference on Human Rights, June 14-25, 1993, Vienna Declaration and Program of

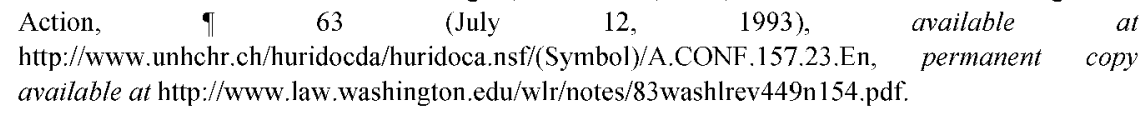

